\title{
SERIOUS ACUTE RESPIRATORY SYNDROME: A CASE SERIES IN A MUNICIPALITY REGION OF CENTRAL BRAZIL
}

\author{
SÍNDROME RESPIRATÓRIA AGUDA GRAVE: SÉRIE DE CASOS EM UM \\ MUNICÍPIO DA REGIÃO CENTRAL DO BRASIL
}

\section{Cácia Régia de PAULA ${ }^{1}$; Eliane Lemes de MORAIS ${ }^{2}$; Patrícia de SÁ BARROS ${ }^{3}$; Ludmila Grego MAIA ${ }^{4}$; Bruno Bordin PELAZZA ${ }^{5}$;uilherme Silva de MENDONÇA ${ }^{6}$; Marcos Lazaro MORELI ${ }^{7}$}

1.7. Nurse. Doctoral student in Nursing at the Faculty of Nursing - Federal University of Goiás. Assistant Professor at the Federal University of Jataí, Goiás, Brazil. cregia@ufg.br; 2. Graduated in nursing from Federal University of Jataí, Goiás, Brazil; 3. Physiotherapist. PhD in Medical Sciences from the Ribeirão Preto Medical School (FMRP), University of São Paulo (USP). Associate Professor at the Federal University of Jataí (UFJ), Goiás, Brazil, 4. Faculty of Nursing, Federal University of Jataí, Goiás, Brazil; 5.

Nurse. Postdoctoral fellow at the Technological Incubator of Guarapuava - INTEG. Nursing department professor from the State University of the Midwest (UNICENTRO); 6. Doctorate in Health Sciences - Federal University of Uberlândia, Nurse at the Hospital de Clinical, Federal University of Uberlândia, Minas Gerais, Brazil; 7. Biomedic, PhD in Clinical Medical Sciences in Ribeirão Preto Medical School (FMRP), University of São Paulo (USP), Master in Ribeirão Preto Medical School (FMRP), University of São Paulo (USP), Associate Professor at Federal University of Jatai (UFJ), Health Science Unit, Pos-Graduate Program in Health Applied Science, Virology Laboratóry (LabVir), Jataí, Goiás, Brazil.

\begin{abstract}
The influenza B virus is more stable than influenza A, with less antigenic drift and consequent immunologic stability, and does not undergo the process of antigenic shift, its participation in epidemics is minimal, being of lesser academic interest. The aim of this work was to describe the occurrence of a series of SARS cases in a municipality in the Central region of Brazil. This is a case series study with a descriptive and quantitative approach of Serious Acute Respiratory Syndrome (SARS) in institutionalized individuals and a health professional from a long-term institution in the municipality where the study was conducted. The variables studied were: age, comorbidities, vaccination status, date of symptoms onset, symptoms, occurrence of death, information regarding provided care (hospital care, exams, and medications). The study was approved by the Research Ethics Committee of the Federal University of Goiás (UFG), under opinion number 2.167.287. Case 1 was diagnosed with influenza $B$, treated with antibiotic therapy, with no antiviral drugs administered, and culminated in death. Cases 2 and 3 were confirmed as influenza B, being treated with antiviral drugs and discharged due to full recovery. Case 4 was confirmed as influenza B virus by epidemiological link, treated with antiviral drugs and discharged due to full recovery. An early diagnosis, adequate clinical management, transmissible disease research based on the 11 health promotion steps and actions can promote the reduction of morbimortality by influenza type B.
\end{abstract}

KEYWORDS: Diagnosis. Epidemiological Investigation. Serious Acute Respiratory Syndrome.

\section{INTRODUCTION}

Influenza is an infectious transmissible viral disease, with a global reach, that can evolve into complications, hospitalisations and death, provoking wide ranging socioeconomic repercussions and epidemics (NG; GORDON, 2015).

Denominated as Myxovirus influenza, it is variable RNA virus, split into types $\mathrm{A}, \mathrm{B}$ and $\mathrm{C}$ (FORLEO-NETO et al., 2003; MARTINEZ, 2009; BARROS et al., 2016).

The influenza $\mathrm{B}$ virus, of which human beings are the principal host is more stable than influenza A, with less antigenic drift and consequent immunologic stability, and does not undergo the process of antigenic shift. due to this, its participation in epidemics is minimal, not causing wide ranging epidemics and, as such, being of lesser academic interest. The influenza B virus attacks more frequently in places like schools and kindergartens, but can also be found in asylums, hostels and others (KASPER; FAUCI, 2015). Commonly affecting children, it can cause death if not treated swiftly and properly (BARROS et al., 2016; GLEZEN, 2014).

The transmission occurs by means of droplets expelled during coughs and sneezing, as well as by respiratory secretion from a contaminated person (SILVA et al., 2015; BRASIL, 2017a; BRASIL, 2017b). The respiratory system impairment associated with acute influenza cases (A, B or C) is called Severe Acute Respiratory Syndrome (SARS) (NG; GORDON, 2015; LENZI et al., 2012; HANNOUN, 2013). 
Serious acute...

Due to the magnitude of the problem, and in light of the deficiency in research on the topic in Brazil, taking into consideration the social, economic and public health repercussions that this aggravating factor can cause, this paper proposes to describe the occurrence of a series of SARS cases in a particular municipality of Central Brazil, as well as their epidemiological investigation/intervention process.

\section{CONTENTS}

This is a case series study of SRAG with descriptive, quantitative and documentary approach, which involved institutionalized individuals and a health professional in a long-term institution in a city in central Brazil. This is a case series study of SRAG with descriptive, quantitative and documentary approach, which involved institutionalized individuals and a health professional in a long-term institution in a city in central Brazil. Thus, the research comprised the use of secondary data available in the Notification Disease Information System (SINAN) Database: Severe Acute Respiratory Syndrome (SRAG) Inpatient or Death by SRAG and the Epidemiological Investigation Report that was carried out by the Center for Epidemiological and Environmental Health Surveillance (NVEAS) of the municipality of the study of these cases, made available by the Municipal Health Secretariat, from January 2015 to January 2016.
PAULA, C. R. et al.

No sample calculation was performed, as it was intended to work with all notified cases of SARS that occurred in the institution. The following inclusion criteria were adopted: SRAG Investigation Sheets that affected users, health professionals and caregivers, and the investigation reports of the cases that occurred in the institution. The following were excluded: SRAG records made available by the Municipal Health Secretariat and case investigation reports, from January 2015 to January 2016, that did not affect users, health professionals and caregivers and that did not occur in the institution. During February 2016, a search and selection of data regarding the compulsory notification of SRAG in the institution was performed. The variables used in the search for the documents were: age, comorbidities, vaccination status, date of onset of symptoms, symptoms, death, information on care provided (hospital care, tests, medications).

As this is secondary information, without identifying the participants, it was not necessary to sign and apply the Informed Consent Form (ICF). The study was authorized by the Municipal Health Department of the municipality and approved by the Research Ethics Committee of the Federal University of Goiás (UFG) of the region where the study was developed, opinion number 2.167.287 / 2017.

The information contained on the SARS worksheets and in research reports, made available by the municipality Health Secretary, were used to describe the cases on Tables 1 and 2.

Table 1. Overview of the cases caused by the influenza B virus in 2015, in a municipality of Central Brazil, 2017.

\begin{tabular}{|c|c|c|c|c|}
\hline Cases & Case 1 & Case 2 & Case 3 & Case 4 \\
\hline Age (years) & 82 & 59 & 34 & 71 \\
\hline Occupation & System User & System User & Health Professional & System User \\
\hline Comorbidities & $\begin{array}{l}\text { Chronic } \\
\text { pneumopathy and } \\
\text { cardiovascular } \\
\text { diseases }\end{array}$ & $\begin{array}{l}\text { Diabetes mellitus } \\
\text { and chronic } \\
\text { pneumopathy }\end{array}$ & ----------- & ------------ \\
\hline $\begin{array}{l}\text { Immunisation } \\
\text { Status }\end{array}$ & $\begin{array}{l}\text { Not vaccinated in } \\
\text { the last } 12 \text { months }\end{array}$ & $\begin{array}{l}\text { Vaccinated in the } \\
\text { last } 12 \text { months }\end{array}$ & $\begin{array}{l}\text { Vaccinated in the } \\
\text { last } 12 \text { months }\end{array}$ & $\begin{array}{l}\text { Vaccinated in the } \\
\text { last } 12 \text { months }\end{array}$ \\
\hline $\begin{array}{l}\text { Symptoms } \\
\text { emergence date }\end{array}$ & $07 / 02 / 2015$ & $08 / 02 / 2015$ & $12 / 02 / 2015$ & $12 / 02 / 2015$ \\
\hline
\end{tabular}




\begin{tabular}{|c|c|c|c|c|}
\hline Symptoms & $\begin{array}{l}\text { Fever, cough, sore } \\
\text { throat, dyspnoea, } \\
\text { respiratory distress, } \\
\text { myalgia, SPO2 < } \\
95 \%\end{array}$ & $\begin{array}{l}\text { Fever, } \\
\text { myalgia }\end{array}$ & $\begin{array}{l}\text { Cough, myalgia, } \\
\text { headache }\end{array}$ & $\begin{array}{l}\text { Fever, } \\
\text { myalgia }\end{array}$ \\
\hline $\begin{array}{l}\text { Admission to } \\
\text { study's municipal } \\
\text { Clinical Hospital }\end{array}$ & On the $10 / 02 / 2015$ & On the $11 / 02 / 15$ & No admission. & $\begin{array}{l}\text { On the } 12 / 02 / 2015 \text {, } \\
\text { for medical } \\
\text { appointment. }\end{array}$ \\
\hline Treatment & $\begin{array}{l}\text { Use of antibiotic } \\
\text { therapy, initiated on } \\
10 / 02 / 2015 \text {. }\end{array}$ & $\begin{array}{l}\text { Use of antiviral } \\
\text { drug, initiated on } \\
13 / 02 / 2015 \text {. }\end{array}$ & $\begin{array}{l}\text { Use of antiviral } \\
\text { drug, initiated on } \\
13 / 02 / 2015 \text {. }\end{array}$ & $\begin{array}{l}\text { Use of antiviral } \\
\text { drug, initiated on } \\
13 / 02 / 2015 \text {. }\end{array}$ \\
\hline Hospital discharge & $\begin{array}{l}\text { On the } 12 / 02 / 2015, \\
\text { with } \\
\text { clinical } \\
\text { progritive } \\
\text { state }\end{array}$ & $\begin{array}{l}\text { On the } 12 / 02 / 2015 \text {, } \\
\text { due to full recovery. }\end{array}$ & ---------------- & ---------------- \\
\hline $\begin{array}{l}\text { Clinical Hospital } \\
\text { readmission }\end{array}$ & $\begin{array}{l}\text { On the } 13 / 02 / 2015 \text {, } \\
\text { with escalation of } \\
\text { the signs and } \\
\text { symptoms. }\end{array}$ & ----------- & ------------ & --------------- \\
\hline Death & $\begin{array}{l}\text { Death on the } \\
15 / 02 / 2015 \text {. }\end{array}$ & ----------- & ------------ & ------- \\
\hline
\end{tabular}

Source: Jataí Municipal Health Secretary.

The exams carried out in each of the cases are presented on Table 2. The authors noted that in one of the cases the Polymerase Chain
Reaction (PCR) exam was not performed, and in three of the cases, there are no references to the $\mathrm{X}$ ray exam.

Table 2. PCR and chest radiograph results for the cases of SARS by the influenza B virus in the year of 2015 , in a municipality of Central Brazil, 2017.

\begin{tabular}{|c|c|c|c|c|c|}
\hline Exams & Case 1 & Case 2 & Case 3 & Case 4 & $\begin{array}{l}\text { Reference } \\
\text { value }\end{array}$ \\
\hline PCR & $\begin{array}{l}\text { Traceable: } \\
\text { Influenza B }\end{array}$ & $\begin{array}{l}\text { Traceable: } \\
\text { Influenza B }\end{array}$ & $\begin{array}{l}\text { Traceable: } \\
\text { Influenza B }\end{array}$ & - & Not traceable \\
\hline $\begin{array}{l}\text { Chest } \\
\text { radiograph }\end{array}$ & - & $\begin{array}{l}\text { Normal } \\
\text { transparency of } \\
\text { the pulmonary } \\
\text { pleurae areas }\end{array}$ & - & - & $\begin{array}{l}\text { Absence of } \\
\text { abnormalities }\end{array}$ \\
\hline
\end{tabular}

Source: Jataí Municipal Health Secretariat.

The report says that on the $13 / 02 / 2015$, a state-wide renowned institution, confirmed case 1 was infected by Influenza type B. That being the case, the hospital surveillance nucleus notified the occurrence of two Influenza $B$ cases to the Epidemiological and Environmental Health Surveillance Nucleus (EEHSN) in the municipality where the study took place. The EEHSN, in light of this information, began an epidemiological investigation by visiting, that same day, the institution where the cases took place.
With the objective of controlling, halting and preventing the transmission of the causative agent, the following procedures were executed: medical appointment for the symptomatic individuals; drug therapy for the treatment of symptomatic individuals; orientations on visiting restrictions; orientations on the use of Individual Protection Equipment (IPE) for the staff; requirement of immunisation record for health workers and institutionalised individuals; orientations on isolation of symptomatic individuals; requesting inspections from the 
Serious acute...

Sanitary Surveillance (SS) and Labour and Employment Ministry (LEM); chemoprophylaxis for the 65 residents and 20 workers associated with the institution; paying visits to family members of the symptomatic patient at their residence; and finally, educational activities for the staff. During the conducted visits, two other symptomatic individuals were detected, in addition to the worsening symptoms of the patient in case 1 . According to the report, these individuals were immediately sent to the hospital unit.

Furthermore, the EEHSN report informed the Sanitary Surveillance (SS) on the 23/02/2015, five days after the release of case 4 patient due to full recovery, of the occurrence of an outbreak at the long-stay institution. According to the SS report, a sanitary inspection was held on the 24/02/2015, with oversights by the institution staff being detected for example, the failure in using IPE by the majority of these.

The present study seeks to present the actions set in motion following the notified cases of SARS and reflects upon the importance of interventions being handled swiftly by the EEHSN.

Professionals that work in long-duration institutions, as well as hosted individuals, run the risk of contamination, as well as spreading infectious diseases to others, thus starting an outbreak. The present study identified that there were delays in the notification of cases, given that outbreak cases should, without fail, be immediately alerted to the epidemiological surveillance, especially in those cases that occur on the premises of a long-stay institution (BRASIL, 2018).

It was noted that the influenza B virus affected people between the ages of 34 and 82 . The influenza B virus can affect individuals of any age, but is more widely found in young adults, adolescents and children. In the elderly, contamination by the A strain is more common, diverging from the cases reported herein (BRASIL, 2016; BRASIL, 2017).

In the present study, the four reported cases showed symptoms compatible with SARS, those being coughing and myalgia as symptoms present in all cases. In case 1, all the signs and symptoms of SARS were detected. According to the treatment protocol, if a patient runs a sudden fever, has an oxygen saturation of less than $95 \%$, dyspnoea or tachypnoea associated with sore throat or cough, and shows one or more of these three symptoms arthralgia, headache or myalgia -, they should be immediately considered and notified as having SARS (BRASIL, 2014a).
PAULA, C. R. et al.

From the cases studied, only three had upto-date immunisation records, and were treated with the antiretroviral medication oseltamivir phosphate (Tamifluß). Cases 3 and 4 presented mild symptoms and had their treatment initiated 24 hours after their manifestation. However, even though case 2 showed mild symptoms, antiviral treatment was only initiated five days after the first signs and symptoms were manifested. In regards to case 1, they did not have an up-to-date immunisation record, with isolated antibiotic treatment therapy being performed and no antiviral medication being administered, which could have aided the escalation and dissemination of the disease.

The use early on of oseltamivir (Tamiflu ${ }^{\circledR}$ ) as influenza treatment enables a significant symptom reduction. It should be administered in cases where risk factors that can intensify the disease are present, even without laboratorial confirmation, regardless of having an up-to-date immunisation record or not (BRASIL, 2014a; BRASIL, 2014b). We can see that even though there was a suspicion of SARS, the immediate treatment, as advised in the protocol, was not initiated, leading to the death of the subject in case 1 .

The four cases admitted to the hospital unit emergency department of the municipality in question received premature leave, even though they were still in the transmissibility stage. It is important to mention that, notwithstanding the measures reported and taken by the epidemiological surveillance team, they did not take into consideration the incubation period of the virus given the case diagnosis. It is known that the period between the exposure to the influenza virus up until the appearance of the first symptoms has a span of one to four days (BRASIL, 2014a) and that transmission takes place between 24 hours before the first signs of symptoms and up to 24 hours after the fever phase ends (SILVA et al., 2015).

Three of the cases described above presented risk factors, those being: age of 65 and above, pneumopathies, and chronic cardiovascular diseases. The study performed by Yano and Tiyo (2013) shows that comorbidities facilitate the action of the causative agent on the body of the elderly, leaving them susceptible to greater aggravation. Therefore, immunisation is the best way for reducing the cases of complications and deaths caused by the influenza virus. Chronic pathologies, which aggravate many diseases, are very common in the elderly, making them a group susceptible to contracting infectious diseases.

On the execution of control exams, only case 2 carried out a chest radiograph, of which the 
report said: normal transparency of the pulmonary pleurae areas, differing from chest radiographs from patients with SARS, where one expects the result to show localised or diffused interstitial infiltrate, or the presence of a condensation area (BRASIL, 2018). In case 4 , the nasopharyngeal exam was not performed, being considered as a clinical epidemiological case. In face of a SARS outbreak, it is suggested that the harvesting for the nasopharyngeal exam should be performed within the first 72 hours, with the objective of rapidly identifying the causative agent (PMBH, 2016). However, this time interval was not observed in the referred cases, where the harvesting was performed at 96 hours (case 1) and 120 hours (case 2) after the initial symptoms start date.

Concerning the actions executed by the EEHSN, one notes that, regarding the cases, some epidemiological investigation steps were skipped. It is a known fact that health surveillance is composed of epidemiological, sanitary, environmental and worker surveillance, and that their functions aim at the health protection of the population, workers and environment (ROUQUAYROL; GURGEL, 2012; OLIVEIRA; CRUZ, 2015). The articulation between these sectors enables the swift identification and control of incidents that may threaten communal health. The reports show a noticeable disarticulation between the different sectors, giving way to the noncompliance of the first step, which is the organisation of the necessary team for the investigation of cases at their occurring localities in an interdisciplinary way, preventing new cases from arising at the institution (ALEXANDRE, 2012; OLIVEIRA; CRUZ, 2015), given that at long term sites, a single case is by itself a source of concern (WHO, 2017; BRASIL, 2018). In regard to the epidemiological investigation of transmissible diseases, 11 steps are recommended to achieve efficiency: idealisation of the actions to be taken in the field; verification of the existence of the outbreak; definition of diagnosis; establishment of hypothesis; investigation of cases and contacts; identification of cases; search for data that may assist in the investigation; final evaluation; interventions; final description and publication or transmission of information concerning the cases to health professionals (ALEXANDRE, 2012; ROUQUAYROL; GURGEL, 2012).

It is possible to ascertain as to whether the likely means of transmission were pre-established, given that for the identification of an outbreak, the individuals that were in contact with the first case should be known, as the risk factors interfere in the propagation and worsening of the remainder (YANO; TIYO, 2013; ALEXANDRE, 2012).

In the tenth step, the team must report the situation to the other health professionals of the municipality and institution, to support them in regard to preventive measures, diagnosis, SARS epidemiological control and treatment, as well as verifying if the implementation of recommended actions are being followed at the institution in question. There are no indications of these actions being taken in the above-mentioned report.

Order No 485 of the Labour and Employment Ministry of 11 November 2005, denominated NR 32 Safety and Health in the Health Services Work Place, has the objective of organising the guidelines that assist in the execution of actions that protect and secures the health of workers. The employer must provide capacitation in an accessible language of easy comprehension on the importance of the use of IPE, and, furthermore, oversee their correct usage (BRASIL, 2005). Noteworthy here is the importance of the role of the SS in overseeing compliance to NR32 (SSESP, 2014). Given that the investigation report does not clearly specify if the staff at the institution were subsequently inspected by the SS team and by the EEHSN to check for compliance regarding the required use of individual protection equipment, we can safely say that the tenth step was not observed. It is noteworthy that in the reports provided by the Municipal Health Secretariat there is no mention of the guidelines of the outbreak and epidemic investigation script proposed by the Ministry of Health, in the Health Surveillance Guide (BASIL, 2017c).

The present study presented limitations in relation to the investigation worksheets and reports, where it was possible to detect incomplete and inconsistent registers. As an example, in the EEHSN report for case 3 , the start of the symptoms was registered as 12/02/2015, while in the PCRinfluenza exam result, it is presented as 08/02/2015. We emphasise that all measures were taken to guarantee the greatest precision possible in regards to the information collected from the reports and worksheets provided.

It is highly significant to highlight just how important public policies are that work hand in hand with high-quality, permanent education actions that aim at raising worker awareness to the importance of aggravation and disease notification, of infection monitoring, in the conduct of care provided to the institutionalised individual and to the importance of compliance to protocols pre-stablished by the relevant bodies (WHO, 2017; FUENTES et al., 2014; BRASIL, 2005). We can conclude that an 
early diagnosis, adequate clinical handling, investigation of transmissible diseases based on the 11 steps, use of IPE, immunisation and other actions that promote good health can be important factors to promote the reduction of morbimortality due to influenza type B. We would like to highlight the importance of empowering the population with more information on the adoption of preventive actions against SARS.
This research did not receive any specific funding from funding agencies, be it from the private, commercial or non-profit sectors.

\section{ACKNOWLEDGEMENTS}

To the Epidemiological and Environmental Health Surveillance Nucleus (EEHSN) team of the municipality where the study took place.

RESUMO: O vírus influenza B é mais estável que a influenza A, apresenta menor desvio antigênico, consequentemente estabilidade imunológica, e não sofre processo de desvio antigênico, não estão associados a grandes epidemias, estando, portanto, pouco associados ao interesse acadêmico. O objetivo do trabalho foi escrever a ocorrência de uma série de casos de Síndrome Respiratória Aguda Grave (SRAG) em um município da região central do Brasil. Trata-se de um estudo de série de casos com abordagem descritiva e quantitativa de SRAG, ocorridos em indivíduos institucionalizados e um profissional de saúde de uma instituição de longa permanência do município onde o estudo foi desenvolvido. As variáveis estudadas foram: idade, comorbidades, situação vacinal, data do início dos sintomas, sintomas, ocorrência de óbito, informações referentes à assistência prestada (atendimento hospitalar, exames, medicações). O estudo foi aprovado pelo Comitê de ética em Pesquisa da Universidade Federal de Goiás (UFG), parecer número 2.167.287. O caso 1 foi diagnosticado com influenza $\mathrm{B}$, tratado com antibioticoterapia, não sendo utilizado antiviral, culminando em óbito. O caso 2 e 3 foram confirmados vírus influenza B, sendo tratados com antiviral e receberam alta por cura. O caso 4 foi confirmado influenza por vírus B por vínculo epidemiológico, tratado com antiviral e recebeu alta por cura. Conclusões: Um diagnóstico precoce, manejo clínico adequado, investigação de doenças transmissíveis pautada nos 11 passos e ações de promoção da saúde, podem promover a redução da morbimortalidade por influenza tipo B.

PALAVRAS-CHAVES: Diagnóstico. Investigação Epidemiológica. Síndrome Respiratória Aguda Grave.

\section{REFERENCES}

ALEXANDRE, L. B. S. P. Epidemiologia Aplicada nos Serviços de Saúde. São Paulo, 2012.

BARROS, E. N. C.; CINTRA, O.; ROSSETTO, E.; FREITAS, L.; COLINDRES, R. Patterns of influenza B circulation in Brazil and its relevance to seasonal vaccine composition. Braz J Infect Dis., Salvador, v. 20 , n. 1 p. 81-90, 2016. http://dx.doi.org/10.1016/j.bjid.2015.09.009.

BRASIL. Ministério do trabalho e emprego. NR 32 - Segurança e saúde no trabalho em serviços de saúde. Portaria MTE n. ${ }^{\circ}$ 485, de 11 de Novembro de 2005 (DOU de 16/11/05 - Seção 1). Brasília, 2005.

BRASIL. Ministério da Saúde. Secretaria de Vigilância em Saúde. Departamento de Vigilância das Doenças Transmissíveis. Protocolo de tratamento de Influenza 2015. Brasília, 2014a.

BRASIL. Ministério da Saúde. Secretaria de Vigilância em Saúde. Departamento de Vigilância das Doenças Transmissíveis. Protocolo de Tratamento de Influenza 2013. Brasília, 2014b.

BRASIL. Ministério da Saúde. Secretaria de Vigilância em Saúde. Informe técnico Campanha Nacional de Vacinação contra a Influenza. Brasília, 2016.

BRASIL. Ministério da Saúde. Secretaria de Vigilância em Saúde. Boletim Epidemiológico. Situação Epidemiológica da Influenza no Brasil até a Semana Epidemiológica 32 de 2017. Brasília, 2017. 
BRASIL. Ministério da Saúde. Influenza. Brasília, 2017a. Disponível em:

http://portalsaude.saude.gov.br/index.php/o-ministerio/principal/secretarias/svs/influenza.

BRASIL. Ministério da Saúde. Aspectos Epidemiológicos. 2017b. Disponível em:

http://portalsaude.saude.gov.br/index.php/informacoes-tecnicas-influenza

BRASIL. Ministério da Saúde. Secretaria de Vigilância em Saúde. Departamento de Vigilância das Doenças Transmissíveis. Protocolo de tratamento de Influenza: 2017 [recurso eletrônico]. Brasília, 2018.

FORLEO-NETO, E.; HALKER, E.; SANTOS, V. J.; PAIVA, T. M.; TONIOLO-NETO, J. Influenza. Rev Soc

Bras Med Trop., Uberaba, v. 36, n. 2, p. 267-274, 2003. http://dx.doi.org/10.1590/S0037-86822003000200011

FUENTES, S. A. M. P. S.; FIGUEIREDO, D.; MERCADANTE, E. F.; LODOVICI, F. M. M.; CERVENY C. M. O. A importância da capacitação e formação de pessoas que trabalham com idosos em Centros-Dia. Rev

Kairós Gerontol., São Paulo, v. 17, n. 3, p. 233-251, 2014. ISSN 1516-2567. ISSNe 2176-901X

GLEZEN, W. P. Changing Epidemiology of Influenza B Virus. Clinical Infectious Diseases, Houston, Texas, v. 59 , n. 11 , p. $1525-6,2014$. DOI: $10.1093 /$ cid/ciu668

HANNOUN, C. The evolving history of influenza viruses and influenza vaccines. Expert Rev Vaccines, Reino Unido, v. 12, n. 9, p. 1085-1094, 2013. DOI: 10.1586/14760584.2013.824709

KASPER, D. L.; FAUCI, A. S. Doenças Infecciosas de Harrison. Rio Grande do Sul, 2 ed., 2015.

LENZI, L.; MELLO, A. M.; SILVA, L. R.; GROCHOCKI, M. H. C.; PONTAROLO, R. Influenza pandêmica A (H1N1) 2009: fatores de risco para o internamento. J Bras Pneumol., São Paulo, v. 38, n. 1, p. 57-65, 2012. http://dx.doi.org/10.1590/S1806-37132012000100009

MARTINEZ, J. A. B. Influenza e publicações científicas. J Bras Pneumol., São Paulo, v. 35, n. 5, p. 399-400, 2009. http://dx.doi.org/10.1590/S1806-37132009000500001

NG, S.; GORDON A. Influenza Burden and Transmission in the Tropics. Curr Epidemiol Rep., Bethesda, USA, v. 2, n. 2 p. 89-100, 2015. doi: 10.1007/s40471-015-0038-4

OLIVEIRA, C. M.; CRUZ, M. M. Sistema de Vigilância em Saúde no Brasil: avanços e desafios. Saúde Debate, Rio de Janeiro, v. 39, n. 104, p. 255-267, 2015. DOI: 10.1590/0103-110420151040385

PMBH - Prefeitura Municipal de Belo Horizonte. Protocolo para atendimento aos pacientes com síndrome gripal (SG) e Síndrome Respiratória Aguda Grave (SRAG). Belo Horizonte, 2016. Acesso em 05 mai 2017. Disponível em: file://C:/Users/Patricia/.spss/Downloads/protocolo-sindromegripal_respiratoria_aguda_grave\%20(2).pdf

ROUQUAYROL, M. Z.; GURGEL, M. Epidemiologia e saúde. Rio de Janeiro, 7 ed., 2012.

SILVA, J. K.; RIBEIRO, M. S. S.; SILVA, J. B.; RIOS, M. A.; GUIMARÃES, C. F.; SOUZA, M. M. A importância do conhecimento quanto ao vírus da influenza A (H1N1): Relato de experiência. Rev Epidemiol Control Infec., Santa Cruz do Sul, v. 5, n. 4, p. 209-211, 2015. http://dx.doi.org/10.17058/reci.v5i4.6192

SSESP - Secretaria de Saúde do Estado de São Paulo. Tema 13. Normas Regulamentadoras n. 7, n. 9, n. 32. Programa de Prevenção de Riscos Ambientais - PPRA; Programa de Controle Médico de Saúde Ocupacional - PCMSO; Segurança e Saúde no Trabalho em Serviços de Saúde. São Paulo, 2014. Disponível em: http://www.saude.sp.gov.br/resources/crh/ggp/cartilhas/normas_regulamentares.pdf

WHO - World Health Organization. Prevention and control of outbreaks of seasonal influenza in long-term care facilities: a review of the evidence and best practice guidance. Dinamarca, 2017. Disponível em: http://www.euro.who.int/_data/assets/pdf_file/0015/330225/LTCF-best-practice-guidance.pdf

YANO, T. K.; TIYO, R. Eficácia da vacina contra influenza em idosos, e sua redução de morte e internamento.

Braz. J. Surg. Clin. Res., Maringá, v. 4, n. 2, p. 46-49, 2013. 